\title{
Pedobacter nyackensis sp. nov., Pedobacter alluvionis sp. nov. and Pedobacter borealis sp. nov., isolated from Montana flood-plain sediment and forest soil
}

\author{
Nathan S. Gordon, Alejandra Valenzuela, Sandra M. Adams, Philip \\ W. Ramsey, Jarrod L. Pollock, William E. Holben and James E. Gannon \\ Microbial Ecology Program, Division of Biological Sciences, The University of Montana, Missoula, \\ MT 59812-1006, USA
}

Correspondence

Nathan S. Gordon

nathan.gordon@umontana.edu

\begin{abstract}
Three Gram-negative, rod-shaped, non-spore-forming eubacterial strains were isolated in western Montana, USA, and subjected to taxonomic studies. Strains NWG- $I 14^{\top}$ and NWER$\| 11^{\top}$ were isolated from hyporheic sediments of a large alluvial flood plain, whereas strain $\mathrm{G}-1^{\top}$ was isolated from a conifer forest soil. On the basis of 16S rRNA gene sequence similarity, strains NWG- $I 14^{\top}$, NWER- $I 111^{\top}$ and $\mathrm{G}-1^{\top}$ were shown to belong to the family Sphingobacteriaceae and are most closely related to various species of the genus Pedobacter. The results of molecular, physiological and biochemical tests allowed genotypic and phenotypic differentiation of these three strains from 23 Pedobacter species with validly published names. The three isolates therefore represent novel species, for which the names Pedobacter nyackensis sp. nov. (type strain NWG-II14 ${ }^{\top}=$ DSM $19625^{\top}=$ LMG 24260 ${ }^{\top}$ ), Pedobacter alluvionis sp. nov. (type strain NWER-II1 $1^{\top}=$ DSM $19624^{\top}=$ LMG $24258^{\top}$ ) and Pedobacter borealis sp. nov. (type strain G-1 ${ }^{\top}$ $=$ DSM $19626^{\top}=$ LMG $24259^{\top}$ ) are proposed.
\end{abstract}

The genus Pedobacter was initially described by Steyn et al. (1998) and, at the time of writing, included 23 species: Pedobacter heparinus, $P$. piscium, $P$. africanus and $P$. saltans (Steyn et al., 1998), P. cryoconitis (Margesin et al., 2003), P. himalayensis (Shivaji et al., 2005), P. caeni (Vanparys et al., 2005), P. sandarakinus (Yoon et al., 2006), P. roseus (Hwang et al., 2006), P. aquatilis (Gallego et al., 2006), P. ginsengisoli (Ten et al., 2006), P. panaciterrae (Yoon et al., 2007a), P. suwonensis (Kwon et al., 2007), P. insulae (Yoon et al., 2007b), P. lentus and P. terricola (Yoon et al., 2007c), P. koreensis (Baik et al., 2007), P. duraquae, P. westerhofensis, $P$. metabolipauper, $P$. hartonius and $P$. steynii (Muurholm et al., 2007) and P. terrae (Yoon et al., 2007d). All of these species are aerophilic or microaerophilic, Gram-negative rods with $\mathrm{MK}-7$ as the predominant isoprenoid quinone and a DNA G + C content of 36$45 \mathrm{~mol} \%\left(T_{\mathrm{m}}\right)$. Four species exhibit gliding motility, five exhibit non-gliding motility and four species have been reported to produce heparinase. Pedobacter species have been isolated from soil, fish, activated sludge, glacier

The GenBank/EMBL/DDBJ accession numbers for the 16S rRNA gene sequences of strains NWG- $I 14^{\top}, \mathrm{G}-1^{\top}$ and NWER- $\| 11^{\top}$ are EU030686, EU030687 and EU030688, respectively.

Fatty acid profiles of strains NWG- $\| 14^{\top}, \mathrm{G}-1^{\top}$ and NWER- $\| 11^{\top}$ and strains of related Pedobacter species are available as supplementary material with the online version of this paper. cryoconite, glacial water, drinking water, fresh water, a hypertrophic pond and a nitrifying enrichment of surface water. This range of habitats suggests that Pedobacter species are generalists, possessing a wide array of enzymes capable of degrading a diverse set of carbon structures for energy. Such metabolic diversity suggests that Pedobacter species have the potential to dominate aerobic heterotrophic microbial communities in various terrestrial and aquatic environments. In this report, the taxonomic characterization of three novel strains that group at the species level with other members of the genus Pedobacter is reported. One of these strains, NWG-II14 ${ }^{\mathrm{T}}$, showed seasonal domination of the readily cultured heterotrophic sediment community of an alluvial flood plain in western Montana.

Sediment and interstitial water samples were collected in sterile tubes from the hyporheic zone of the Nyack flood plain along the Middle Fork of the Flathead River, Montana, USA. Soil samples were collected from the rhizosphere of a western Montana conifer forest. During the isolation of organisms extracted from hyporheic sediments and soil, strains NWG-II $14^{\mathrm{T}}$, NWER-II $11^{\mathrm{T}}$ and G $-1^{\mathrm{T}}$ were recovered on environmental water agar (EWA), a Gelrite (Sigma) layer over dilute one-tenth-strength R2A agar (Difco) and undiluted R2A agar, respectively. EWA was composed of $1 \%$ agarose (Sigma) and filter-sterilized 
formation water from wells on the flood plain. EWA was used to provide the bacterial community with nutrient levels that most closely represented in situ conditions. The Gelrite layer was used to encapsulate bacterial cells in a 3D matrix and solidified using divalent cations contained in the underlying dilute R2A agar. All plates were incubated aerobically for $2-4$ weeks at $10{ }^{\circ} \mathrm{C}$ in the dark (in situ temperature ranges seasonally from 4 to $12{ }^{\circ} \mathrm{C}$ ). Initial colonies of strain NWG-II1 $14^{\mathrm{T}}$ on EWA were $0.2-0.5 \mathrm{~mm}$ in diameter, round and transparent, with creamy white centres developing after 6 weeks of incubation. Initial colonies of strains NWER-II $11^{\mathrm{T}}$ and $\mathrm{G}-1^{\mathrm{T}}$ on Gelrite and $\mathrm{R} 2 \mathrm{~A}$ agar, respectively, were $0.3-1.0 \mathrm{~mm}$ in diameter, round and produced a reddish pigment. All isolates were subsequently cultivated on one-fifth-strength R2A agar at $10{ }^{\circ} \mathrm{C}$ for 7 days. On this medium, all strains were able to grow at $4-32{ }^{\circ} \mathrm{C}$, but not at 0 or $37{ }^{\circ} \mathrm{C}$. Growth of all strains was also observed at 10 and $30{ }^{\circ} \mathrm{C}$ on tryptic soy agar (TSA; Difco) and nutrient agar (NA; Difco). No growth was observed on MacConkey agar (BBL).

Nearly full-length $16 \mathrm{~S}$ rRNA gene sequences of strains NWG-II $14^{\mathrm{T}}$, NWER-II $11^{\mathrm{T}}$ and G-1 ${ }^{\mathrm{T}}$ were obtained by direct PCR amplification of $1 \mu \mathrm{l}$ culture (grown as described above) using the primers 27f, 907r and 1492r (Lane, 1991) and 536f (Holben et al., 2004). PCR products were purified using the QIAquick PCR purification kit (Qiagen) according to the manufacturer's instructions and then subjected to direct bidirectional DNA sequence analysis (Murdock Molecular Biology Facility, University of Montana, Missoula). The Sequence Match version 3 component of the Ribosomal Database Project was used to determine $S_{\mathrm{ab}}$ scores (similarity $a$ versus $b$ ) that indicate the closest matching relatives of the three strains. $S_{\mathrm{ab}}$ scores are generated by calculating the number of unique $7 \mathrm{bp}$ oligomers shared between two partial $16 \mathrm{~S}$ rRNA sequences divided by the smallest number of unique 7-mers in either sequence (Cole et al., 2007). BLAST 2 SEQUENCES was used to generate 16S rRNA gene sequence similarities (Tatusova \& Madden, 1999). Similarity scores indicated that strain NWG-II14 ${ }^{\mathrm{T}}$ was most closely related to the type strains of P. caeni $\left(S_{\mathrm{ab}}=0.895 ; 97.2 \%\right.$ sequence similarity), P. steynii $\left(S_{\mathrm{ab}}=0.890 ; 97.7 \%\right)$ and P. heparinus $\left(S_{\mathrm{ab}}=0.884 ; 97.4 \%\right)$. Strain NWER-II1 $1^{\mathrm{T}}$ was most closely related to the type strains of $P$. roseus $\left(S_{\mathrm{ab}}=0.927 ; 98.9 \%\right), P$. sandarakinus $\left(S_{\mathrm{ab}}=0.882 ; 97.3 \%\right)$ and P. suwonensis $\left(S_{\mathrm{ab}}=0.870 ; 97.5 \%\right)$. Strain $\mathrm{G}-1^{\mathrm{T}}$ was most closely related to the type strains of $P$. sandarakinus $\left(S_{\mathrm{ab}}=0.895 ; \quad 98.1 \%\right), \quad P . \quad$ suwonensis $\left(S_{\mathrm{ab}}=0.894 ; 98.2 \%\right)$ and $P$. roseus $\left(S_{\mathrm{ab}}=0.883 ; 98.0 \%\right)$.

Multiple alignments were performed with the sequences of these novel strains and the type strains of species with validly published names obtained from the NCBI GenBank database (Wheeler et al., 2000; Benson et al., 2000) for the genera Sphingobacterium and Pedobacter using CLUSTAL_X (Thompson et al., 1997). PAUP version 4.0 beta 10 (Swofford, 2003) was used to generate phylogenetic trees using the neighbour-joining (Saitou \& Nei, 1987) and maximum-parsimony (Kluge \& Farris, 1969) algorithms.
PAUP was also used to generate bootstrap support for all tree topologies using 1000 random replicates from the original sequence data (Felsenstein, 1985). Strains NWG$\mathrm{II} 14^{\mathrm{T}}$, NWER-II1 $1^{\mathrm{T}}$ and $\mathrm{G}-\mathrm{1}^{\mathrm{T}}$ clustered with members of the genus Pedobacter with a bootstrap resampling value of $100 \%$ (Fig. 1). On the basis of the phylogenetic data, it is clear that the three novel strains should be classified in the genus Pedobacter.

For chemotaxonomic analyses, cell biomass was obtained from cells cultured in one-fifth-strength $\mathrm{R} 2 \mathrm{~A}$ broth at $20{ }^{\circ} \mathrm{C}$. Isoprenoid quinones were extracted and purified according to Collins et al. (1977) with the TLC modification as noted by Tamaoka et al. (1983). Purified isoprenoid quinones were analysed by reversed-phase HPLC using a Phenomenex Synergi 4u Fusion-RP 80A $(250 \times 4.6 \mathrm{~mm})$ column. Phospholipid fatty acids were extracted from cell pellets and analysed by the method of White \& Ringelberg (1998) as described previously by Rillig et al. (2006). The $\mathrm{G}+\mathrm{C}$ content of the genomic DNA of strains NWG-II14 ${ }^{\mathrm{T}}$, NWER-II $11^{\mathrm{T}}$ and G-1 ${ }^{\mathrm{T}}$ was determined by HPLC analysis of deoxyribonucleosides according to the method of Mesbah et al. (1989), using a reversed-phase column (Synergi 4u Fusion-RP 80A; Phenomenex).

DNA-DNA hybridization experiments were conducted between strain NWER-II $11^{\mathrm{T}}$ and P. roseus JCM $13399^{\mathrm{T}}$ (98.9\% 16S rRNA gene sequence similarity) and between strain G- $1^{\mathrm{T}}$ and P. suwonensis DSM $18130^{\mathrm{T}}(98.2 \% 16 \mathrm{~S}$ rRNA gene sequence similarity) by the Deutsche Sammlung von Mikroorganismen und Zellkulturen (Braunschweig, Germany). DNA-DNA relatedness values were determined in duplicate and mean values were calculated. DNA was isolated using a French pressure cell (ThermoSpectronic) and was purified by chromatography on hydroxyapatite as described by Cashion et al. (1977). DNA-DNA hybridization experiments were carried out as described by De Ley et al. (1970) with the modifications described by Huß et al. (1983) using a Cary 100 Bio UV/ VIS-spectrophotometer equipped with a Peltier-thermostatted $6 \times 6$ multicell changer and a temperature controller with in situ temperature probe (Varian).

Cell morphology and motility were determined using a Zeiss Axioskop light microscope at $\times 1000$ with cells grown for 3 days at $10{ }^{\circ} \mathrm{C}$ on TSA. Gram-staining reaction and catalase and oxidase activities were tested according to the methods of Gerhardt et al. (1994). Heparinase activity was detected by the method of Joubert et al. (1984). Carbon assimilation and enzyme production tests were conducted using API $50 \mathrm{CH}$, API $20 \mathrm{NE}$ and API ZYM strips (bioMérieux) under aerobic conditions.

Strains NWG-II $14^{\mathrm{T}}$, NWER-II $11^{\mathrm{T}}$ and $\mathrm{G}-1^{\mathrm{T}}$ possessed biochemical characteristics that associated them with members of the genus Pedobacter and differentiated them from members of the genus Sphingobacterium (Steyn et al., 1998). They lacked urease activity and did not assimilate melezitose. The major isoprenoid quinone of the three strains was MK-7. The DNA G $+\mathrm{C}$ contents of strains 


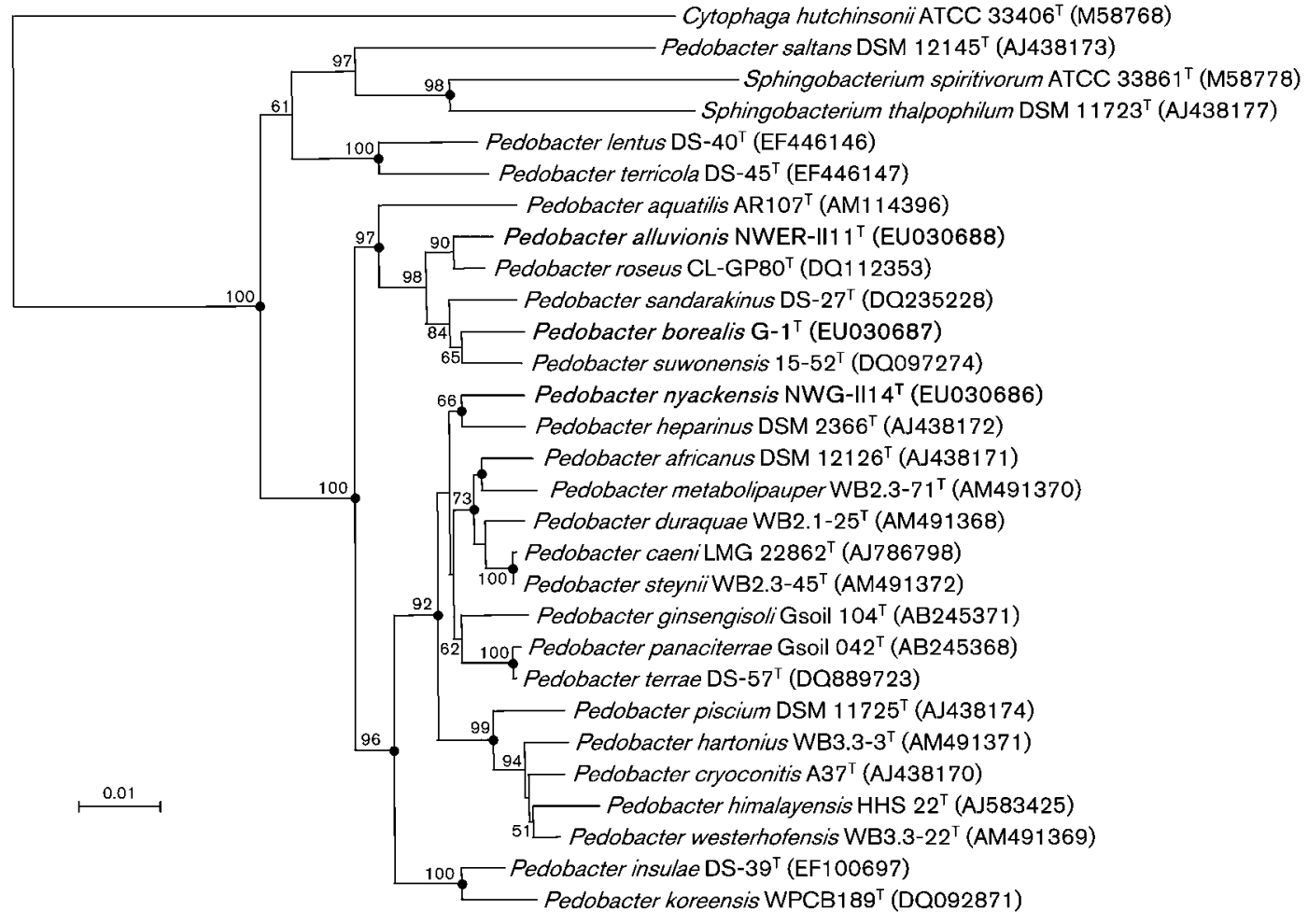

Fig. 1. Neighbour-joining tree based on $16 \mathrm{~S}$ rRNA sequences showing the phylogenetic positions of strains NWG-Il14 ${ }^{\top}$, NWER-II $11^{\top}$ and $\mathrm{G}-1^{\top}$ in relation to the type strains of 23 Pedobacter and two Sphingobacterium species. Cytophaga hutchinsonii ATCC $33406^{\top}$ was used as a monophyletic outgroup. Bootstrap support values greater than $50 \%$ (percentages of 1000 replicates) are shown at branch points. Filled circles indicate nodes that were also recovered using maximum-parsimony algorithms. Bar, 0.01 substitutions per nucleotide site.

NWG-II14 ${ }^{\mathrm{T}}$, NWER-II $11^{\mathrm{T}}$ and $\mathrm{G}-1^{\mathrm{T}}$ were $41.1 \pm 0.4$, $39.3 \pm 0.6$ and $39.7 \pm 0.5 \mathrm{~mol} \%$, respectively. These values are consistent with the $36-45 \mathrm{~mol} \%$ range previously suggested for the genus Pedobacter (Steyn et al., 1998). All three strains contained iso- $\mathrm{C}_{15: 0}$, iso- $\mathrm{C}_{17: 0} \quad 3-\mathrm{OH}$, $\mathrm{C}_{16: 1} \omega 5 c$ and $\mathrm{C}_{16: 1} \omega 7 c$ as major cellular fatty acids, which is also in accordance with the description of the genus Pedobacter (Steyn et al., 1998). The fatty acid compositions of strains NWG-II14 ${ }^{\mathrm{T}}$, NWER-II1 $1^{\mathrm{T}}, \mathrm{G}-1^{\mathrm{T}}$ and strains of related Pedobacter species are detailed in Supplementary Table S1, available in IJSEM Online. Strains NWER-II1 $11^{\mathrm{T}}$ and G- $1^{\mathrm{T}}$ exhibited low levels of DNA-DNA relatedness to P. roseus JCM $13399^{\mathrm{T}}(6.3 \%)$ and P. suwonensis DSM $18130^{\mathrm{T}}(4.4 \%)$, respectively, indicating that both strains are unique at the species level according to the recommended threshold of $70 \%$ DNA-DNA similarity (Wayne et al., 1987). In contrast to other members of the genus Pedobacter (except $P$. suwonensis), strains NWG-II14 ${ }^{\mathrm{T}}$, NWER-II $11^{\mathrm{T}}$ and G-1 $1^{\mathrm{T}}$ demonstrated $\alpha$-fucosidase activity.

On the basis of the phylogenetic, phenotypic and chemotaxonomic data presented, strains NWG-II14 ${ }^{\mathrm{T}}$, NWER-II $11^{\mathrm{T}}$ and $\mathrm{G}-1^{\mathrm{T}}$ are proposed as the type strains of three novel species in the genus Pedobacter, for which the names Pedobacter nyackensis sp. nov., Pedobacter alluvionis sp. nov. and Pedobacter borealis sp. nov., respectively, are proposed.

\section{Description of Pedobacter nyackensis sp. nov.}

Pedobacter nyackensis (ny.ack.en'sis. N.L. masc. adj. nyackensis from Nyack, a region of north-western Montana, USA).

Colonies grown on TSA for $48 \mathrm{~h}$ at $20{ }^{\circ} \mathrm{C}$ are $0.5-5.0 \mathrm{~mm}$ in diameter, round, convex, opaque and beige, darkening with age. Cells are Gram-negative, oxidase- and catalasepositive, non-motile, non-spore-forming rods (0.2$0.7 \times 1.0-4.0 \mu \mathrm{m}$ ), with an oxidative metabolism. Good growth is observed after $96 \mathrm{~h}$ at 10 and $30{ }^{\circ} \mathrm{C}$ on TSA, NA and R2A. Growth does not occur at $37^{\circ} \mathrm{C}$ or on MacConkey agar. Growth occurs at $\mathrm{pH}$ 5-10 (optimal $\mathrm{pH}$ 7-8). It can be differentiated from other Pedobacter species with validly published names by its ability to assimilate L-sorbose; it can be differentiated from its closest phylogenetic relatives, $P$. caeni, $P$. heparinus and $P$. africanus, by its ability to assimilate glycogen and 2ketogluconate. The fatty acid profile is composed of $\mathrm{C}_{14: 0}$, iso- $\mathrm{C}_{15: 0}$, iso- $\mathrm{C}_{15: 0} 2-\mathrm{OH}, \mathrm{C}_{16: 1} \omega 7 c$ and $\mathrm{C}_{16: 1} \omega 5 c$. The major isoprenoid quinone is MK-7. Additional phenotypic properties are shown in Table 1. 
Table 1. Differential characteristics of strains NWGIII $4^{\top}$, NWERII11 ${ }^{\top}$ and G-1 ${ }^{\top}$ and phylogenetically related species of the genus Pedobacter

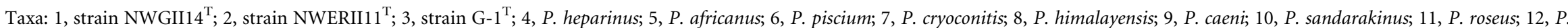

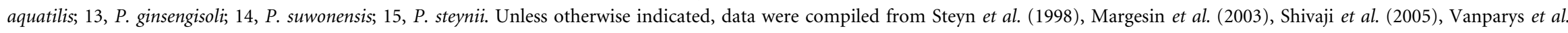

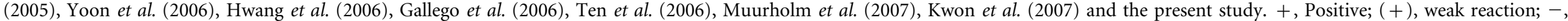

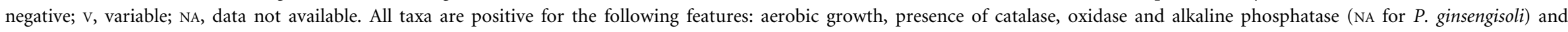

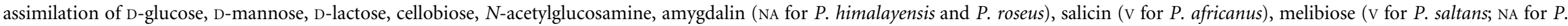

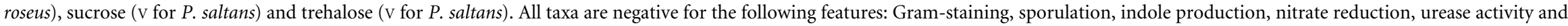
assimilation of D-lyxose (NA for P. himalayensis and P. roseus), D-fucose (NA for P. himalayensis and P. roseus), erythritol (NA for P. roseus and P. ginsengisoli), inositol and dulcitol.

\begin{tabular}{|c|c|c|c|c|c|c|c|c|c|c|c|c|c|c|c|}
\hline Characteristic & 1 & 2 & 3 & 4 & 5 & 6 & 7 & 8 & 9 & 10 & 11 & 12 & 13 & 14 & 15 \\
\hline Source & $\begin{array}{c}\text { Flood-plain } \\
\text { sediment }\end{array}$ & $\begin{array}{l}\text { Flood-plain } \\
\text { sediment }\end{array}$ & Soil & Soil & $\begin{array}{l}\text { Soil, activated } \\
\text { sludge }\end{array}$ & Fish & $\begin{array}{l}\text { Glacier } \\
\text { cryoconite }\end{array}$ & $\begin{array}{r}\text { Glacier } \\
\text { water }\end{array}$ & $\begin{array}{l}\text { Nitrifying } \\
\text { inoculum }\end{array}$ & Soil & $\begin{array}{l}\text { Hypertrophic } \\
\text { freshwater }\end{array}$ & $\begin{array}{c}\text { Drinking } \\
\text { water }\end{array}$ & Soil & $\begin{array}{c}\text { Cabbage rhi- } \\
\text { zosphere }\end{array}$ & $\begin{array}{c}\text { Hard-water } \\
\text { creek }\end{array}$ \\
\hline Growth temperature range $\left({ }^{\circ} \mathrm{C}\right)$ & $<2-32$ & $4-30$ & $4-30$ & $5-30$ & $\mathrm{NA}$ & $5-30$ & $1-25$ & $4-25$ & NA & $4-33$ & $5-33$ & $4-30$ & $4-30$ & $1-37$ & $10-30$ \\
\hline DNA G $+C$ content $(\mathrm{mol} \%)$ & 41.1 & 39.3 & 39.7 & $42-43$ & $43-45$ & $40-43$ & 43.4 & 41.0 & 42.7 & 39.7 & 41.3 & 38 & 43.6 & 44.2 & NA \\
\hline Gelatin hydrolysis & - & + & + & - & $\mathrm{V}$ & - & + & + & - & - & + & - & - & + & - \\
\hline Arginine dihydrolase & - & + & + & - & - & $\mathrm{NA}$ & - & + & - & - & - & - & - & - & - \\
\hline Heparinase & + & - & - & + & + & - & - & + & $\mathrm{NA}$ & NA & - & $\mathrm{NA}$ & NA & - & - \\
\hline \multicolumn{16}{|l|}{ Assimilation of (API 50CH): } \\
\hline Glycerol & - & - & - & - & - & - & - & + & - & - & + & - & + & - & + \\
\hline D-Arabinose & - & + & - & - & $\mathrm{V}$ & - & - & + & - & - & $\mathrm{NA}$ & - & - & - & - \\
\hline L-Arabinose & + & + & + & - & $\mathrm{V}$ & - & + & + & + & - & + & + & - & + & - \\
\hline D-Ribose & + & + & - & + & $\mathrm{V}$ & + & - & + & - & - & - & - & - & - & - \\
\hline D-Xylose & + & - & + & + & $\mathrm{V}$ & - & + & + & - & - & $\mathrm{NA}$ & - & + & + & + \\
\hline L-Xylose & - & - & - & - & - & - & - & + & + & - & + & - & + & - & $\mathrm{NA}$ \\
\hline D-Adonitol & - & + & - & + & - & - & - & + & - & - & $\mathrm{NA}$ & - & - & - & - \\
\hline Methyl $\beta$-D-xyloside & - & + & - & - & - & - & - & $\mathrm{NA}$ & - & - & $\mathrm{NA}$ & - & NA & $\mathrm{NA}$ & - \\
\hline D-Galactose & + & + & + & + & + & $\mathrm{V}$ & + & + & - & + & + & + & + & + & - \\
\hline D-Fructose & + & + & + & + & $\mathrm{V}$ & + & + & + & - & - & + & + & + & $(+)$ & - \\
\hline L-Sorbose & + & + & - & - & - & - & - & - & - & - & $\mathrm{NA}$ & - & - & - & $\mathrm{NA}$ \\
\hline L-Rhamnose & + & + & + & + & + & $\mathrm{V}$ & - & + & - & - & + & + & - & + & - \\
\hline D-Mannitol & - & - & - & + & - & - & - & + & - & - & - & - & - & - & - \\
\hline D-Sorbitol & - & - & - & + & - & - & - & + & - & - & - & - & - & - & - \\
\hline Methyl $\alpha$-D-mannoside & + & + & + & + & + & - & - & + & + & $(+)$ & $\mathrm{NA}$ & + & NA & + & - \\
\hline Methyl $\alpha$-D-glucoside & + & + & + & + & + & + & $(+)$ & + & + & $(+)$ & $\mathrm{NA}$ & + & NA & + & + \\
\hline Arbutin & + & + & + & $\mathrm{v}$ & $\mathrm{V}$ & + & + & + & + & - & $\mathrm{NA}$ & + & NA & + & + \\
\hline Aesculin & + & + & + & + & + & + & + & + & + & + & + & + & - & + & + \\
\hline Maltose & + & + & + & + & $\mathrm{V}$ & + & + & + & + & + & + & + & + & + & + \\
\hline Inulin & + & + & - & - & - & - & $(+)$ & + & + & - & + & - & + & - & - \\
\hline Melezitose & - & - & - & - & - & - & - & - & - & - & $\mathrm{NA}$ & + & NA & + & - \\
\hline Raffinose & + & + & + & - & - & + & + & + & + & - & + & + & + & + & + \\
\hline Starch & + & + & + & - & $\mathrm{V}$ & + & + & + & + & + & $\mathrm{NA}$ & + & - & + & + \\
\hline Glycogen & + & - & - & - & - & - & + & - & - & + & + & - & - & + & + \\
\hline Xylitol & - & - & - & - & - & - & - & - & + & - & $\mathrm{NA}$ & - & - & - & - \\
\hline$\beta$-Gentiobiose & + & + & + & + & $\mathrm{v}$ & + & + & $\mathrm{NA}$ & + & + & $\mathrm{NA}$ & + & $\mathrm{NA}$ & + & + \\
\hline
\end{tabular}


Table 1. cont.

\begin{tabular}{|c|c|c|c|c|c|c|c|c|c|c|c|c|c|c|c|}
\hline Characteristic & 1 & 2 & 3 & 4 & 5 & 6 & 7 & 8 & 9 & 10 & 11 & 12 & 13 & 14 & 15 \\
\hline Turanose & + & + & + & + & + & + & + & NA & - & - & NA & + & $\mathrm{NA}$ & + & + \\
\hline D-Tagatose & - & - & - & - & - & - & - & NA & - & - & $\mathrm{NA}$ & - & $\mathrm{NA}$ & $\mathrm{NA}$ & - \\
\hline L-Fucose & - & - & - & + & $\mathrm{V}$ & - & - & + & - & - & $\mathrm{NA}$ & - & $\mathrm{NA}$ & - & - \\
\hline D-Arabitol & - & - & - & - & - & - & - & NA & - & - & $\mathrm{NA}$ & - & $\mathrm{NA}$ & NA & - \\
\hline L-Arabitol & - & - & - & - & - & - & - & NA & - & - & $\mathrm{NA}$ & - & NA & $\mathrm{NA}$ & - \\
\hline Gluconate & - & - & - & - & - & - & - & + & - & - & - & - & - & $\mathrm{NA}$ & - \\
\hline 2-Ketogluconate & + & - & - & - & - & - & + & NA & - & - & $\mathrm{NA}$ & - & $\mathrm{NA}$ & NA & - \\
\hline 5-Ketogluconate & + & - & + & - & - & - & - & NA & - & + & $\mathrm{NA}$ & - & $\mathrm{NA}$ & $\mathrm{NA}$ & - \\
\hline \multicolumn{16}{|l|}{ Enzyme activity (API ZYM) } \\
\hline Esterase & + & + & + & $\mathrm{V}$ & - & $\mathrm{V}$ & $\mathrm{NA}$ & NA & - & + & + & + & $\mathrm{NA}$ & + & + \\
\hline Esterase lipase & + & + & + & + & + & + & - & NA & + & + & + & + & $\mathrm{NA}$ & + & + \\
\hline Lipase & - & - & - & - & - & $\mathrm{V}$ & - & - & - & - & - & - & - & - & - \\
\hline Leucine arylamidase & + & + & + & + & + & + & $\mathrm{NA}$ & NA & + & + & + & + & $\mathrm{NA}$ & + & + \\
\hline Valine arylamidase & + & + & + & - & V & $+^{*}$ & $\mathrm{NA}$ & NA & - & - & + & + & $\mathrm{NA}$ & + & + \\
\hline Cystine arylamidase & + & + & + & $\mathrm{V}$ & - & $+^{*}$ & $\mathrm{NA}$ & NA & - & $(+)$ & - & + & $\mathrm{NA}$ & - & - \\
\hline Trypsin & - & + & + & - & - & $+^{*}$ & $\mathrm{NA}$ & NA & - & - & + & + & $\mathrm{NA}$ & + & $\mathrm{NA}$ \\
\hline Chymotrypsin & - & - & - & $\mathrm{V}$ & - & $+^{*}$ & $\mathrm{NA}$ & NA & - & - & + & - & $\mathrm{NA}$ & - & NA \\
\hline Acid phosphatase & + & + & + & + & + & + & $\mathrm{NA}$ & + & + & + & + & + & $\mathrm{NA}$ & + & $\mathrm{NA}$ \\
\hline $\begin{array}{l}\text { Naphthol-AS-BI-phosphohy- } \\
\text { drolase }\end{array}$ & + & + & + & + & + & $\mathrm{NA}$ & $\mathrm{NA}$ & NA & - & + & + & + & $\mathrm{NA}$ & + & + \\
\hline$\alpha$-Galactosidase & + & + & + & $\mathrm{V}$ & - & $+^{*}$ & $\mathrm{NA}$ & NA & - & - & + & - & $\mathrm{NA}$ & - & $\mathrm{NA}$ \\
\hline$\beta$-Galactosidase & + & + & + & + & + & + & + & + & + & + & $\mathrm{V}$ & + & - & + & + \\
\hline$\beta$-Glucuronidase & - & - & + & - & - & $\mathrm{V}^{*}$ & $\mathrm{NA}$ & NA & - & - & - & - & $\mathrm{NA}$ & - & $\mathrm{NA}$ \\
\hline$\alpha$-Glucosidase & + & + & + & + & + & + & $\mathrm{NA}$ & NA & - & + & + & + & $\mathrm{NA}$ & + & + \\
\hline$\beta$-Glucosidase & + & + & $\mathrm{v}$ & $\mathrm{V}$ & $\mathrm{V}$ & $+^{*}$ & + & + & - & + & - & + & $\mathrm{NA}$ & + & + \\
\hline$N$-Acetyl- $\beta$-glucosaminidase & + & + & + & + & + & + & $\mathrm{NA}$ & NA & - & + & + & + & $\mathrm{NA}$ & + & + \\
\hline$\alpha$-Mannosidase & + & - & - & $\mathrm{V}$ & $\mathrm{V}$ & $+^{*}$ & $\mathrm{NA}$ & NA & - & - & - & + & $\mathrm{NA}$ & - & - \\
\hline$\alpha$-Fucosidase & + & + & + & - & - & $-*$ & $\mathrm{NA}$ & NA & - & - & - & - & $\mathrm{NA}$ & + & - \\
\hline
\end{tabular}

${ }^{*}$ Data from Takeuchi \& Yokota (1992). 
The type strain is NWG-II14 ${ }^{\mathrm{T}}\left(=\mathrm{DSM} 19625^{\mathrm{T}}=\mathrm{LMG}\right.$ $24260^{\mathrm{T}}$ ), isolated from hyporheic sediments of the Nyack flood plain in north-western Montana, USA. The DNA $\mathrm{G}+\mathrm{C}$ content of the type strain is $36.1 \mathrm{~mol} \%$.

\section{Description of Pedobacter alluvionis sp. nov.}

Pedobacter alluvionis (al.lu.vi.o' nis. L. gen. n. alluvionis of alluvial land).

Colonies grown on TSA for $48 \mathrm{~h}$ at $20{ }^{\circ} \mathrm{C}$ are $0.2-2.0 \mathrm{~mm}$ in diameter, round, convex, opaque and have a reddishpink pigment. Cells are Gram-negative, oxidase- and catalase-positive, non-motile, non-spore-forming rods $(0.3-0.6 \times 1.0-3.0 \mu \mathrm{m})$, with an oxidative metabolism. Good growth is observed after $96 \mathrm{~h}$ at 10 and $30{ }^{\circ} \mathrm{C}$ on TSA, NA and R2A. Growth does not occur at $37^{\circ} \mathrm{C}$ or on MacConkey agar. Growth occurs at pH 5-10 (optimal $\mathrm{pH} 7-8)$. It can be differentiated from other Pedobacter species with validly published names by its ability to assimilate methyl $\beta$-D-xyloside and L-sorbose; it can be differentiated from its closest phylogenetic relatives, $P$. roseus, $P$. sandarakinus and $P$. aquatilis, by the presence of arginine dihydrolase activity and its ability to assimilate Darabinose, D-ribose and D-adonitol. The fatty acid profile is composed of $\mathrm{C}_{14: 0}$, iso- $\mathrm{C}_{15: 0}$, iso- $\mathrm{C}_{15: 0} 2-\mathrm{OH}, \mathrm{C}_{16: 1} \omega 07 \mathrm{c}$ and $\mathrm{C}_{16: 1} \omega 5 c$. The major isoprenoid quinone is MK-7. Additional phenotypic properties are shown in Table 1.

The type strain is NWER-II11 ${ }^{\mathrm{T}}\left(=\mathrm{DSM} 19624^{\mathrm{T}}=\mathrm{LMG}\right.$ $24258^{\mathrm{T}}$ ), isolated from hyporheic sediments of the Nyack flood plain in north-western Montana, USA. The DNA $\mathrm{G}+\mathrm{C}$ content of the type strain is $34.4 \pm 0.2 \mathrm{~mol} \%$.

\section{Description of Pedobacter borealis sp. nov.}

Pedobacter borealis (bo.re.a'lis. M.L. masc. adj. borealis related to the north, boreal).

Colonies grown on TSA for $48 \mathrm{~h}$ at $20{ }^{\circ} \mathrm{C}$ are $0.2-2.0 \mathrm{~mm}$ in diameter, round, convex, opaque and have a reddishpink pigment. Cells are Gram-negative, oxidase- and catalase-positive, non-motile, non-spore-forming rods $(0.3-0.5 \times 0.7-3.0 \mu \mathrm{m})$, with an oxidative metabolism. Good growth is observed after $96 \mathrm{~h}$ at 10 and $30{ }^{\circ} \mathrm{C}$ on TSA, NA and R2A. Growth does not occur at $37^{\circ} \mathrm{C}$ or on MacConkey agar. Growth occurs at $\mathrm{pH}$ 5-7 (optimal $\mathrm{pH} 7$ ). It can be differentiated from other Pedobacter species with validly published names by the presence of the enzyme $\beta$-glucuronidase; it can be differentiated from its closest phylogenetic relatives, $P$. sandarakinus, $P$. roseus and $P$. aquatilis, by the presence of arginine dihydrolase activity and its ability to assimilate D-xylose. The fatty acid profile is composed of $\mathrm{C}_{14: 0}$, iso- $\mathrm{C}_{15: 0}$, iso- $\mathrm{C}_{15: 0} 2-\mathrm{OH}, \mathrm{C}_{16: 1} \omega 7 c$ and $\mathrm{C}_{16: 1} \omega 5 c$. The major isoprenoid quinone is MK-7. Additional phenotypic properties are shown in Table 1.

The type strain is $\mathrm{G}-1^{\mathrm{T}}\left(=\mathrm{DSM} 19626^{\mathrm{T}}=\mathrm{LMG} 24259^{\mathrm{T}}\right)$, isolated from the rhizosphere of a conifer forest in western
Montana, USA. The DNA G $+\mathrm{C}$ content of the type strain is $35.5 \pm 0.5 \mathrm{~mol} \%$.

\section{Acknowledgements}

Special thanks go to the Dalimata family, Brian Reid and Jack Stanford's team at the Flathead Lake Biological Station for their help in facilitating this research. This work was supported by National Science Foundation Microbial Observatory grant no. MCB-0348773.

\section{References}

Baik, K. S., Park, Y.-D., Kim, M. S., Park, S. C., Moon, E. Y., Rhee, M. S., Choi, J. H. \& Seong, C. N. (2007). Pedobacter koreensis sp. nov., isolated from fresh water. Int J Syst Evol Microbiol 57, 20792083.

Benson, D. A., Karsch-Mizrachi, I., Lipman, D. J., Ostell, J., Rapp, B. A. \& Wheeler, D. L. (2000). GenBank. Nucleic Acids Res 28, 15-18.

Cashion, P., Holder-Franklin, M. A., McCully, J. \& Franklin, M. (1977). A rapid method for base ratio determination of bacterial DNA. Anal Biochem 81, 461-466.

Cole, J. R., Chai, B., Farris, R. J., Wang, Q., Kulam-Syed-Mohideen, A. S., McGarrell, D. M., Bandela, A. M., Cardenas, E., Garrity, G. M. \& Tiedje, J. M. (2007). The ribosomal database project (RDP-II): introducing $m y \mathrm{RDP}$ space and quality controlled public data. Nucleic Acids Res 35, D169-D172.

Collins, M. D., Pirouz, T., Goodfellow, M. \& Minnikin, D. E. (1977). Distribution of menaquinones in actinomycetes and corynebacteria. $J$ Gen Microbiol 100, 221-230.

De Ley, J., Cattoir, H. \& Reynaerts, A. (1970). The quantitative measurement of DNA hybridization from renaturation rates. Eur $J$ Biochem 12, 133-142.

Felsenstein, J. (1985). Confidence limits on phylogenies: an approach using the bootstrap. Evolution 39, 783-791.

Gallego, V., García, M. T. \& Ventosa, A. (2006). Pedobacter aquatilis sp. nov., isolated from drinking water, and emended description of the genus Pedobacter. Int J Syst Evol Microbiol 56, 1853-1858.

Gerhardt, P., Murray, R. G. E., Wood, W. A. \& Krieg, N. R. (editors) (1994). Methods for General and Molecular Bacteriology. Washington, DC: American Society for Microbiology.

Holben, W. E., Feris, K. P., Kettunen, A. \& Apajalahti, J. H. A. (2004). GC fractionation enhances microbial community diversity assessment and detection of minority populations of bacteria by denaturing gradient gel electrophoresis. Appl Environ Microbiol 70, 2263-2270.

Huß, V. A. R., Festl, H. \& Schleifer, K. H. (1983). Studies on the spectrophotometric determination of DNA hybridization from renaturation rates. Syst Appl Microbiol 4, 184-192.

Hwang, C. Y., Choi, D. H. \& Cho, B. C. (2006). Pedobacter roseus sp. nov., isolated from a hypertrophic pond, and emended description of the genus Pedobacter. Int J Syst Evol Microbiol 56, 1831-1836.

Joubert, J. J., van Rensburg, E. J. \& Pitout, M. J. (1984). A plate method for demonstrating the breakdown of heparin and chondroitin sulfate by bacteria. J Microbiol Methods 2, 197-202.

Kluge, A. G. \& Farris, J. S. (1969). Quantitative phyletics and the evolution of anurans. Syst Zool 18, 1-32.

Kwon, S.-W., Kim, B.-Y., Lee, K.-H., Jang, K.-Y., Seok, S.-J., Kwon, J.-S., Kim, W.-G. \& Weon, H.-Y. (2007). Pedobacter suwonensis sp. nov., isolated from the rhizosphere of Chinese cabbage (Brassica campestris). Int J Syst Evol Microbiol 57, 480-484. 
Lane, D. J. (1991). 16S/23S rRNA sequencing. In Nucleic Acid Techniques in Bacterial Systematics, pp. 115-175. Edited by E. Stackebrandt \& M. Goodfellow. Chichester: Wiley.

Margesin, R., Spröer, C., Schumann, P. \& Schinner, F. (2003). Pedobacter cryoconitis sp. nov., a facultative psychrophile from alpine glacier cryoconite. Int J Syst Evol Microbiol 53, 1291-1296.

Mesbah, M., Premachandran, U. \& Whitman, W. B. (1989). Precise measurement of the $\mathrm{G}+\mathrm{C}$ content of deoxyribonucleic acid by highperformance liquid chromatography. Int J Syst Bacteriol 39, 159-167.

Muurholm, S., Cousin, S., Päuker, O., Brambilla, E. \& Stackebrandt, E. (2007). Pedobacter duraquae sp. nov., Pedobacter westerhofensis sp. nov., Pedobacter metabolipauper sp. nov., Pedobacter hartonius sp. nov. and Pedobacter steynii sp. nov., isolated from a hard-water rivulet. Int J Syst Evol Microbiol 57, 2221-2227.

Rillig, M. C., Mummey, D. L., Ramsey, P. W., Klironomos, J. N. \& Gannon, J. E. (2006). Phylogeny of arbuscular mycorrhizal fungi predicts community composition of symbiosis-associated bacteria. FEMS Microbiol Ecol 57, 389-395.

Saitou, N. \& Nei, M. (1987). The neighbor-joining method: a new method for reconstructing phylogenetic trees. Mol Biol Evol 4, 406-425.

Shivaji, S., Chaturvedi, P., Reddy, G. S. N. \& Suresh, K. (2005). Pedobacter himalayensis sp. nov., from the Hamta glacier located in the Himalayan mountain ranges of India. Int J Syst Evol Microbiol 55, 1083-1088.

Steyn, P. L., Segers, P., Vancanneyt, M., Sandra, P., Kersters, K. \& Joubert, J. J. (1998). Classification of heparinolytic bacteria into a new genus, Pedobacter, comprising four species: Pedobacter heparinus comb. nov., Pedobacter piscium comb. nov., Pedobacter africanus sp. nov. and Pedobacter saltans sp. nov. Proposal of the family Sphingobacteriaceae fam. nov. Int J Syst Bacteriol 48, 165-177.

Swofford, D. L. (2003). PAUP*: Phylogenetic analysis using parsimony ( ${ }^{*}$ and other methods), version 4.0B10. Sunderland, MA: Sinauer Associates.

Takeuchi, M. \& Yokota, A. (1992). Proposals of Sphingobacterium faecium sp. nov., Sphingobacterium piscium sp. nov., Sphingobacterium heparinum comb. nov., Sphingobacterium thalpophilum comb. nov., and two genospecies of the genus Sphingobacterium and synonymy of Flavobacterium yabuuchiae and Sphingobacterium spiritivorum. J Gen Appl Microbiol 38, 465-482.

Tamaoka, J., Katayama-Fujimura, Y. \& Kuraishi, H. (1983). Analysis of bacterial menaquinone mixtures by high performance liquid chromatography. J Appl Bacteriol 54, 31-36.
Tatusova, T. A. \& Madden, T. L. (1999). BLAST 2 Sequences, a new tool for comparing protein and nucleotide sequences. FEMS Microbiol Lett 174, 247-250.

Ten, L. N., Liu, Q.-M., Im, W.-T., Lee, M., Yang, D.-C. \& Lee, S.-T. (2006). Pedobacter ginsengisoli sp. nov., a DNase-producing bacterium isolated from soil of a ginseng field in South Korea. Int J Syst Evol Microbiol 56, 2565-2570.

Thompson, J. D., Gibson, T. J., Plewniak, F., Jeanmougin, F. \& Higgins, D. G. (1997). The CLUSTAL_X windows interface: flexible strategies for multiple sequence alignment aided by quality analysis tools. Nucleic Acids Res 25, 4876-4882.

Vanparys, B., Heylen, K., Lebbe, L. \& De Vos, P. (2005). Pedobacter caeni sp. nov., a novel species isolated from a nitrifying inoculum. Int J Syst Evol Microbiol 55, 1315-1318.

Wayne, L. G., Brenner, D. J., Colwell, R. R., Grimont, P. A. D., Kandler, O., Krichevsky, M. I., Moore, L. H., Moore, W. E. C., Murray, R. G. E. \& other authors (1987). International Committee on Systematic Bacteriology. Report of the ad hoc committee on reconciliation of approaches to bacterial systematics. Int J Syst Bacteriol 37, 463-464.

Wheeler, D. L., Chappey, C., Lash, A. E., Leipe, D. D., Madden, T. L., Schuler, G. D., Tatusova, T. A. \& Rapp, B. A. (2000). Database resources of the National Center for Biotechnology Information. Nucleic Acids Res 28, 10-14.

White, D. C. \& Ringelberg, D. B. (1998). Signature lipid biomarker analysis. In Techniques in Microbial Ecology, pp. 255-272. Edited by R. S. Burlage, R. Atlas, D. Stahl, G. Geesey \& G. Sayler. Oxford: Oxford University Press.

Yoon, J.-H., Lee, M.-H., Kang, S.-J., Park, S.-Y. \& Oh, T.-K. (2006). Pedobacter sandarakinus sp. nov., isolated from soil. Int J Syst Evol Microbiol 56, 1273-1277.

Yoon, M.-H., Ten, L. N., Im, W.-T. \& Lee, S.-T. (2007a). Pedobacter panaciterrae sp. nov., isolated from soil in South Korea. Int J Syst Evol Microbiol 57, 381-386.

Yoon, J.-H., Kang, S.-J., Oh, H. W. \& Oh, T.-K. (2007b). Pedobacter insulae sp. nov., isolated from soil. Int J Syst Evol Microbiol 57, 19992003.

Yoon, J.-H., Kang, S.-J., Park, S. \& Oh, T.-K. (2007c). Pedobacter lentus sp. nov. and Pedobacter terricola sp. nov., isolated from soil. Int J Syst Evol Microbiol 57, 2089-2095.

Yoon, J.-H., Kang, S.-J. \& Oh, T.-K. (2007d). Pedobacter terrae sp. nov., isolated from soil. Int J Syst Evol Microbiol 57, 2462-2466. 